\title{
A Disclose the Competence of Auditors Relationship with Partners in A Audit Quality
}

\author{
Viati Nurhidayati*; Iwan Triyuwono; Abdul Ghofar \\ University of Brawijaya, Indonesia \\ Email: via.is.mom@gmail.com
}

http://dx.doi.org/10.18415/ijmmu.v5i6.510

\begin{abstract}
A business development demands financial transparency to support success in business competition. It was evidenced by the financial statements of auditors who can provide confidence for investors, which is the desire to invest in a company. Therefore, accountant services are needed for the business development world because reliability of a financial report that it can only be assessed by a professional auditor in the field of accounting. This study was used a qualitative method with an ethnometology approach. The results show that a friend relationship has an impact on the audit quality produced. Recruiting relatives without regard to their competencies makes some audit procedures often overlooked. So, it has taken some several stages such as acceptance of engagement, planning an audit, carrying out field work, and reporting for the audit. Therefore, a successful of the auditor to produce a audit quality is very important start from the acceptance of engagement. This phenomenon is the basis of this research, where the work of one of the KAP auditors affiliated with foreign consultants has a relationship with a partner.
\end{abstract}

Keywords: Competence; Kinship; Audit Quality

\section{Introduction}

The development of business in the world is largely influenced by family businesses. Even the family business is the biggest contributor to improving a country's economy. Based on a survey conducted by Price Waterhouse Cooper (Pwc) about 95\% more, companies in Indonesia are family businesses. The Public Accountant Office is a family business with the form of a business family (BF), where the family as the owner of the company tends to emphasize kinship. Whereas, in developing countries the narrowness of employment leads to intense competition among job seekers. So, usually relying on relatives who have worked is one solution for individuals who have not got a job.

Making use of nepotism does not only appear in the recent era. In the New Order era, the leadership of the Indonesian President Soeharto occurred in many cases of nepotism. After the collapse of the new order era turned into an era of reform, it is expected that cases of nepotism that are identical to cases of corruption can be eliminated. However, in fact the case of nepotism which has led to corruption and is capable of harming the state up to billions of rupiahs is still happening. In 2014 Banten Governor 
Atut Chosiyah was proven to have committed a crime of nepotism with a loss of 79,7 billion for the procurement of medical devices carried out by his younger brother Tubagus Chaeri Wardhana (Fadhil., 2017). Nepotism crime does not only occur among politicians who occupy structural positions in government but also occur in the world of education, in 2017 the chancellor of one of the state universities in Jakarta appointed his biological children and son-in-law to become lecturers and campus officials. Appointment of family members to become lecturers and campus officials is considered as maladministration or abuse of authority (Nadlir., 2017).

The phenomenon that occurs in KAP " $\mathrm{X}$ " shows that the low auditor competence causes the end of an agreement. The KAP Auditor " $\mathrm{X}$ " also ignores the stages of the audit, especially at the audit planning stage while at the audit planning stage, the auditor is expected to understand the client's business so that the auditor can add information, determine the initial materiality and understand and carry out SPI testing. Based on the above phenomena that occur in KAP " $\mathrm{X}$ " partners should recruit relatives while maintaining their competency.

Relatives recruited by partners to become an auditor should have sufficient competence in order to produce a quality audit. However, if the auditor's recruitment does not pay attention to the competencies possessed, this can affect the way the KAP works as a whole and the quality of the audit produced. Therefore, a partner should properly recruit employees. Recruitment is the process of finding, finding and attracting capable applicants to be employed in and by an organization (Siagian., 2014: 102).

The auditor is the tip of the audit process milestone because the auditor is the party that interacts directly with the client. Thus, the ability and competence of auditors are the basis of client satisfaction. This is in line with Muawanah (2014) which states that nepotism carried out by leaders as owners by recruiting relatives to become employees can make good or bad governance depending on how the owner uses that authority.

The auditor can be said to have good audit quality if the auditor is able to find a violation and dare to disclose it. This is in line with Fauji's (2015) statement which states that audit quality for users of financial statements is a belief given by the auditor to the auditee's financial statements that there is no material fraud or misstatement. The audit quality for auditors is seen as compliance with the Public Accountant Professional Standards (SPAP) issued by the IAPI (Indonesian Institute of Certified Public Accountants) as an institution that houses professional auditors.

A public accountant is expected to carry out his duties professionally to produce good audit quality by maintaining independence, having competence and professional ethics. However, many assumptions say that audit quality is equivalent to the reputation possessed by a KAP. This assumption is based on the assumption that the audits carried out by large and bona fide KAPs will be handled professionally compared to medium and small scale KAPs so that the quality of the output produced is better.

According to Clank and Ken (2012) said that KAP must have adequate resources and to fulfill these requirements in recruiting prospective auditors, KAP staff must recruit competent auditors. An auditor's competency can be obtained through formal education and non-formal education that is relevant to the world of accounting and auditing. The lack of competencies possessed by auditors as experts can influence how the auditor prepares the audit process, preparation of working papers until the release of the Independent Auditor's Report. Lee \& Stone (1995) in deli (2015) defines competence as sufficient expertise that can be explicitly used to conduct audits objectively.

Clank and Ken (2012) said that KAP must have adequate resources and to meet these requirements in recruiting prospective auditors, KAP staff must recruit competent auditors. The lack of 
competency of an auditor and staff at the Public Accounting Office can affect the overall performance of the KAP and the quality of the audit produced. Therefore, a partner should properly recruit employees.

The damage to KAP's reputation due to low audit quality was also experienced by KAP Purwanto, Suherman and Surja affiliated with KAP Ernst and Young (EY). Failure of Purwanto, Suherman and Surja KAPs to provide supporting evidence for the calculation of 4,000 cell tower towers in PT Indosat Tbk's financial statements in 2011 caused the Public Company Accounting Oversight Board (PCAOB) to sanction a fine of US \$ 1 million to Ernst and Young Indonesia, US \$ 20,000 to partner EY Indonesia Roy Iman Wirahardja, then a fine of US \$10,000 and a ban on practicing for a year to former Director of EY Asia-Pacific, Randall Leali.

With the re-emergence of the PwC case in India until the ban on auditing the Satyam Computer company by the Indian capital market regulator was effective in March 2018 due to a corporate scandal. further strengthen the argument for the importance of audit quality supported by competence and understanding and the implementation of good audit procedures. Ramalinga Raju as the owner of Satyam Computer admitted that he had made false financial statements in 2009 with inflating profits and assets, at that time $\mathrm{PwC}$ was his auditor. Thus, it is very clear that $\mathrm{PwC}$ does not carry out audit procedures with good or low competence of auditors who are "downgraded" so that $\mathrm{PwC}$ cannot conduct fraud detection by Satyam Computer (NN., 2007).

The phenomenon of the release of engagement on general audit services that occurred in one of the KAPs in Malang due to dissatisfaction with the performance and minimum competence possessed by the executing auditor is clear evidence that the recruitment of auditors on the basis of a family relationship by ignoring competence provides a separate problem for KAP. The low level of auditor competence has an impact on the low quality of audits produced due to lack of planning and poor implementation of audit procedures. Good planning can be done by an experienced, skilled, and good analytical auditor and holds the principle of prudence in implementing audit procedures so that it can support confidence in the management assertions in the form of financial statements. An adequate experience can be obtained by an accountant through being directly involved in the assignment and understanding the standards of the public accounting profession.

In this study, researchers tried to uncover a phenomenon of kinship that is very "thick" with the order of life of the people of Indonesia is no exception in the world of work, especially public accounting services. Researchers believe there are other things that have not been touched by previous research such as how the competence of auditors who have a close relationship with partners during the audit process takes place.

This study will try to see whether KAP in Indonesia, especially in Malang, East Java, has good audit quality even though there are elements of kinship in it. Considering that KAP is formed with two or more people who bind themselves to work together (partnership), each of which has family and relatives. By considering the kinship relationship inherent in the Javanese community, this study attempts to examine the phenomenon of recruitment of relatives as competent auditors to produce quality audits.

Where, the existence of KAP "X" in a small town that is full of local values with the characteristics of small and medium-sized KAPs, but has been affiliated with foreign KAPs which are assumed to have a more modern perspective. This research was carried out by trying to understand the rationality of practice in the daily activities of the objects in the observation. According to Kamayanti (2017) states that researchers must objectify the subjectivity of the behavior of an organization.

Based on the phenomena described in the background above, the existence of a Public Accountant Office as a professional organization requires every auditor to have sufficient competence in 
order to be able to provide quality audits to external parties. However, the existence of local KAP which is full of kinship relations in it makes its own problems. In this case, it is often the recruitment of relatives without regard to the competencies they have. Thus, the researcher focused on this research to uncover audit quality from auditors who have a close relationship with partners through their daily activities during the engagement. The researcher makes the question in this study is how the auditor works with a relative relationship with the partner in carrying out the engagement to produce good audit quality related to the competencies he has.

This research is intended to obtain answers to the phenomena that occur in the KAP " $\mathrm{X}$ ". The phenomenon of each partner and owner can employ close relatives (core) and seminaries in the business environment that they run by ignoring their competencies. Auditor competence can be known during the audit process. Revealing the competence of an auditor can be done by observing the workings of the auditor when the engagement begins until the issuance of LAI. Thus in order to be able to answer the above problems, this study uses an ethnometodology approach. Data collection in the form of observations and interviews conducted by researchers is expected to be used for analysis of phenomena that occur in KAP "X".

\section{Theoritical}

\section{Selection of Qualitative Research}

In this case, the suitable approach for this research is a qualitative approach. Moleong (2014) states that qualitative approaches are used to understand a phenomenon experienced by research objects such as behavior, perceptions, motivations and actions as a whole. Where, try to look at audit quality related to auditor competency from another perspective by paying attention to kinship relations in KAP. Relative relations in Indonesian society have very broad meanings so that measurements with numerical units in the form of a Likert scale cannot represent the meaning contained therein. Therefore, qualitative research requires a strong commitment to be able to spend time in the field and is willing to enter research areas with high complexity (Sukoharsono., 2006).

Ethnometodology as a way of reacting to the competence of auditors who have a relationship with a partner

This study uses a non-positivistic paradigm to understand the phenomenon of kinship that occurs in KAP "X" in Malang City. Ethnometodology approach is one of the clusters of the interpretive paradigm by producing words and language, which comes from the description of behavior, motivation, and actions taken by the subject of research. Researchers focus on social environments where a great deal of information on the phenomenon of disclosure is decided by researchers, which is then called a natural setting (Moleong., 1989; Maykut \& Morehouse., 1994).

Ethnometodology was first developed by Harold Garfinkel who carried out the development of the phenomenology introduced by Edmund Huserl. If phenomenology is rooted in individual consciousness, then ethnometodology begins with the unconsciousness of individuals in groups as members of the community. The researcher must be able to bring amazement to everything that happens, to let go of all kinds of judgment realities (Kamayanti., 2017: 139).

\section{Research Site}

This research was conducted in one of the local KAPs located in Malang City. KAP " $\mathrm{X}$ " is a small-scale KAP that is affiliated with a foreign consultant, is expected to have a perspective and have a 
better way of working. It is undeniable that the way Westerners work is better by prioritizing professionalism. However, KAP " $\mathrm{X}$ " is not able to apply professional attitude during the audit process. The lack of professionalism that occurs in KAP "X" can be caused by the presence of a local culture in the form of family or kinship attitudes that are very inherent in Javanese society, recruiting family members or close and distant relatives. Recruitment of relatives based on a sense of wanting to help, prosper or elevate economic status is the main reason.

Attitudes ignore the lack of competence, skills, and knowledge possessed by relatives as the main requirements for becoming an auditor. So, this has an impact on the low understanding of audit procedures and makes the quality results low. The attitude of partners who should be as quality control can spur the auditor to continue to improve self-quality, but not because there is reluctance between partners with one another. KAP " $\mathrm{X}$ " which is identical with kinship relations raises a feeling of reluctance to reprimand each other or remind when one of the auditors made a mistake.

\section{Object of Research}

The object of the research is the auditor's work which is a daily activity in KAP "X". The way the auditor works is very much related to competence, the better the competency that an auditor has, the better the mechanism of audit work. This is because auditors who have good competence will try to add skills and knowledge and work in accordance with SPAP. KAP " $\mathrm{X}$ " located in Malang City was established with a business family model emphasizing kinship relationships so that the recruitment of employees both as auditors and KAP staff mostly came from relatives. Recruitment is intended to prosper family members and tends to ignore the competencies they have. In line with the research conducted by Muawanah (2014) which says that businesses with kinship models tend to have incentives to operate efficiently, but on the other hand, tendencies towards nepostism (for example the management selection from the closest incompetent people).

\section{Qualitative Data}

The instrument in qualitative research is the researcher himself besides the words and actions taken by the informant. According to Moleong (2014), the main data sources in qualitative research are in the form of words and actions obtained from informants such as documents or other data. But in ethnometodology research, information in the form of words not only comes from the results of interviews but can also come from observing conversations that occur between auditors in KAP "X".

\section{Data Collection Technique}

Creswell (2016: 206) explains that data collection is a series of activities that are interrelated with each other and have a purpose for gathering information. 


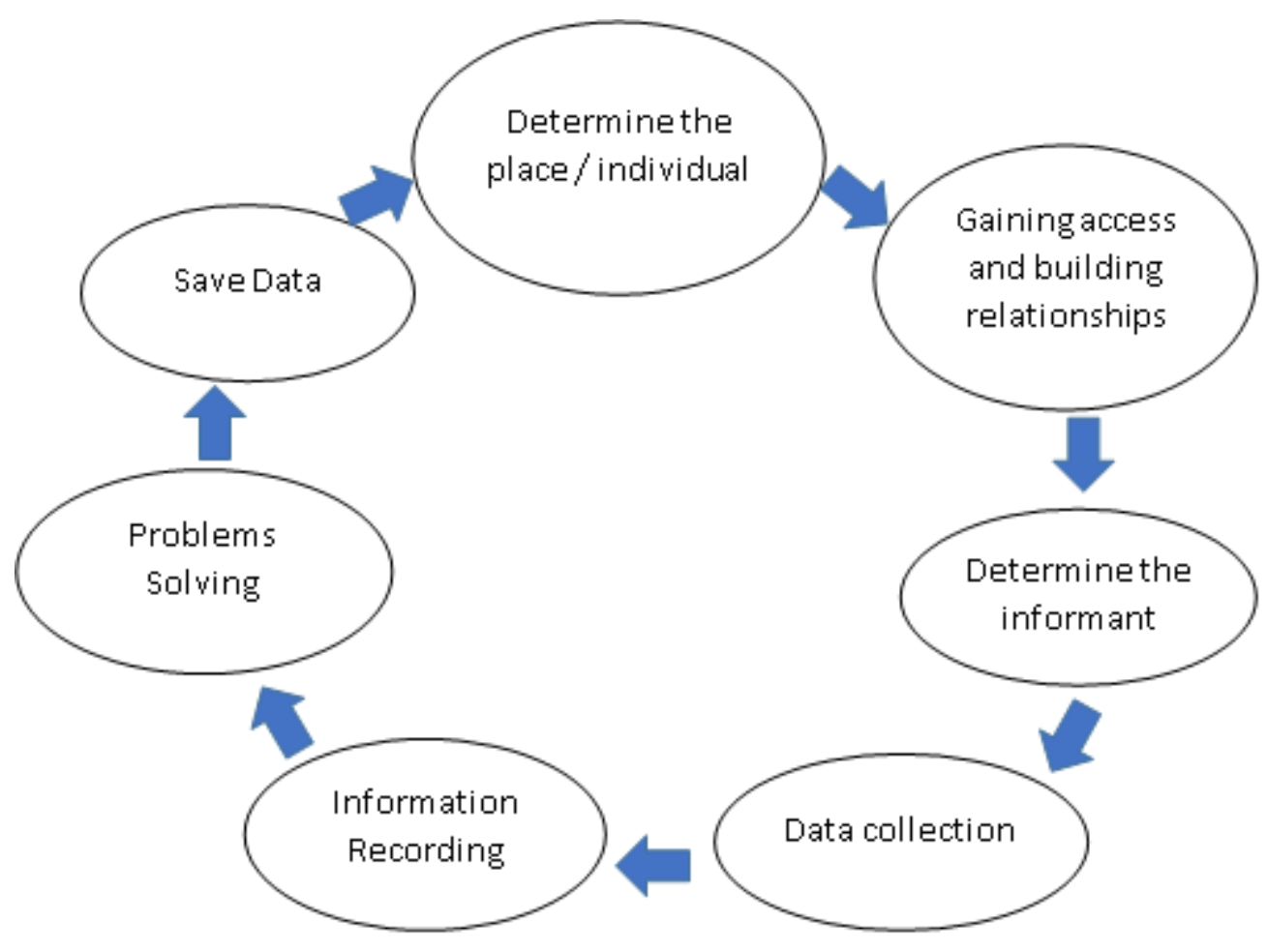

Fig. 1 Data collection activities

Source: Creswell (2016: 207) with adjusted changes

\section{Following Is the Description of Data Collection Activities}

1. The first step, determine the place/ individual. The researcher determined KAP "X" in Malang City as the object of research because $\mathrm{KAP}$ " $\mathrm{X}$ " was the place where the researcher worked in it.

2. Gaining access and building relationships, where it aims to obtain information in data collection.

3. Determination of informants in this study is based on kinship.

The informant who will interview only 1 person is the senior auditor with the initials $\mathrm{N}$ who has a close relationship with a partner and has worked for seventeen years. He has an economics education background and has conducted general audits in various types of businesses. The selection of auditor $\mathrm{N}$ as an informant is because in addition to having a family relationship, the $\mathrm{N}$ auditor is also a permanent employee at KAP. The use of 1 informant conducted by the researcher aims that the results of the research are in-depth about the competence of an auditor who has a kinship relationship with a partner during the audit process.

The researcher also reviewed and recorded secondary data sources in the form of documents that supported the research. The assessment of documents relevant to the research is used as supplementary evidence to uncover the social realities that occur in KAP. Secondary. 


\section{Data Analysis Technique}

Ethnometodology as a way to understand daily activities that have three stages of analysis (Garfinkel., 1967). The first step is the search for indexicality, the second stage is reflexivity which underlies practical action, and the third stage is achieving contextual action that can be analyzed. In the first stage of indexicality analysis, ethnometodologists (researchers) get the task of finding words or expressions that are assumed to be only possessed by the revealer and limited by time and place (Kamayanti., 2017). Maynard and Clayman (1991) say that the clarity of words or expressions is very much tied to the situation in a community. For example, "he has a family relationship in this company." The expression of relatives in the sociology study means that the person has a blood relationship with one of the parties in the company, but said relatives can be different if seen in business studies which can be interpreted as nepotism.

\section{Results}

\section{Assessing SPI on the Basis of A Mere Compulsion}

Understanding the client business aims to conduct internal control as a means of control so that the entity is achieved properly. Therefore, the auditor must understand the preparation of the audit plan. Understanding SPI as a basis for identifying the types of potential misstatements and possible fraud that could potentially affect the financial statements, consider several factors that have an impact on the risk of material misstatement, and design substantive testing. This is done during the afternoon after lunch time, where the researcher asks the auditor $\mathrm{N}$ to find out how much understanding auditor $\mathrm{N}$ is concerned about the need to understand the client's business in planning the audit.

The importance of understanding and assessing SPI clients in the planning stage is intended as the basis for gathering competent evidence and determining the extent of substantive testing. However, the reality found in the "X" KAP understands the SPI at the planning stage as limited to working paper procedures. Auditor N carries out the SPI assessment procedure but does not understand from every step he has taken and is recorded in the audit work paper. Auditor N's paperwork is neatly arranged and easily understood by other parties, but this is the opposite for N. Auditor N's auditor as a professional in carrying out tasks based on supervisor's instructions without conducting further review, review and understanding of the performance. This is due to the low level of understanding and knowledge possessed by the $\mathrm{N}$ auditor. Thus, $\mathrm{N}$ auditor competence as a professional in auditing services is directly proportional to the knowledge possessed.

\section{Collection of Audit Evidence as a Basis for Giving Opinion}

Auditing Standard (SA) 200 paragraph 11 states that the audit of financial statements aims to obtain adequate confidence about whether the financial statements prepared as a whole are free from material misstatement, whether caused by fraud or error so that the auditor can express an opinion on the financial statements according with the applicable financial reporting framework. In obtaining adequate confidence, the auditor needs to understand the standards of field work. Standard fieldwork consists of good and structured planning. When using an assistant, supervision needs to do an audit as a professional. Thus, it is necessary to understand internal controls adequately in addition to understanding auditing standards and the auditor must obtain competent audit evidence through inspection observations, information requests and confirmation as a basis for giving opinion statements on the client's financial statements. Therefore, through the careful planning phase the audit can be done well. 
Audit procedures at the implementation stage of the overall field work have been carried out by $\mathrm{N}$. auditors. The workings of collecting audit evidence on events after the balance sheet date, collecting audit evidence through minutes of meeting, requesting management statements as written evidence that financial statements are the responsibility of management, performing procedures analytical, sampling techniques, audit procedures for each account to analyze and evaluate the evidence of the transaction have been carried out properly. However, the $\mathrm{N}$ auditor does not understand the meaning of each procedure appropriately. Audit procedures conducted by auditor $\mathrm{N}$ based on experience and imitating previous auditor partners. The lack of auditor N's understanding of the meaning of audit procedures as well as the low level of knowledge possessed by auditors $\mathrm{N}$ makes audit procedures carried out on the basis of the "e principal", so that this results in the low quality of audits produced.

After making observations through work methods and confirming the informants related to the implementation of audit procedures starting from the acceptance stage of the engagement until the publication of the Independent Auditor Report (LAI). The researcher gained a belief that kinship relations had an impact on the quality of the audit produced. Recruiting relatives without regard to their competencies makes several audit procedures often overlooked. Auditor competency is shown through work methods at each stage of the audit procedure and not only the implementation phase of the field work but also the stage of acceptance of the engagement. Therefore, the auditor's success in producing a quality audit starts from the acceptance of the engagement. This phenomenon is the basis of this research, where the work of one of the KAP auditors affiliated with foreign consultants has a relationship with a partner.

Audit procedures have an inseparable set of ways to produce quality audits. Knowledge and understanding of audit procedures can help auditors carry out audits well in order to collect audit evidence as a basis for giving opinions. Kinship can reduce audit quality produced by a KAP, because the recruitment of auditors is less competent. Feeling mutual love and mutual love for each other is one of the main reasons for receiving relatives to be part of the group and participate in running business activities without considering their competencies.

\section{Conclusion}

This study aims to reveal the phenomenon of the competence of auditors who have kinship relationships with partners to produce quality and good audits. At the stage of acceptance of the engagement, the auditor has low knowledge about the need to evaluate management integrity to third parties, identify financial reporting frameworks to provide assurance that financial statements are prepared consistently in accordance with applicable accounting standards, the need for audit requests from clients that should be carried out written and low understanding of the auditor related to the reason for the change in the proposal. At the planning stage of the audit, the auditor carries out audit procedures only to complete the working paper without understanding the purpose of the procedure. In the third stage of the implementation of field work, the auditor carries out all audit procedures as a mechanism for collecting audit evidence but the auditor does not understand and knows the function of each procedure at the stage of field work so that the auditor is less able to modify or add detailed testing to the balance in the field. The last stage is the stage of audit reporting, audit procedures such as giving opinions, meeting drafts and revisions to audit reports if errors occur have been carried out systematically. The lack of knowledge and understanding of auditors shows the low competence possessed by auditors, this can have an impact on the quality of the audit produced. 


\section{Limitation}

The limitations or weaknesses felt by researchers in the process of this research are that the research site is the workplace of the researcher. Researchers working in KAP " $\mathrm{X}$ " for more than five years make researchers difficult to get the wow-effect mindest, difficulties bring amazement to everything as the researchers first saw. Researchers have become part of the KAP "X" so that researchers have difficulty releasing themselves from various forms of judgment on reality as required in ethnometodology. However, researchers try their best to keep holding objectivity in the subjectivity of researchers.

\section{References}

Aranya, N and Amernic, J. P. (1981). "An Examination of Professional Commited in Public AccountTing," Accounting Organization and Society, 6(4).

Arens, A. A., Elder, R.J., and Beasley, M.S. (2012). "Auditing and Assurance Ser-vice-An Integrated Approach". 14th Edition.Pearson Education Limited, Ed-inburg UK.

Ashari, H and Winarto, Y. (2017). Mitra Ernst \& Young Indonesia Didenda US\$ 1 juta. Retrieved from http://nasional.kontan.co.id/news/mitra-ernst-young-indonesia-didenda-us-1-juta to date 31 Januari 2018.

Bowlin, K. O., Jessen, L. H., and M David, P. (2013). The Effects of Auditor Ro-tation, Professional Skepticism, and Interections with Managers on Audit Quali-ty.

Boynton, william c., et al. (2001). Modern Auditing (Edisi ketujuh jilid 1, dialih bahasakan oleh paul A. Rajoe, Gina Gania, ichsan setiyo budi). Jakarta: Erlangga.

Burrel, G., and Morgan, G. (1979). Sociological Paradigm and Organisational Analysis. London: Heinemann Educational Books Ltd.

Choi, J. H., Kim, F., Kim, J.B. and Zang, Y.S. (2010). Audit Office Size, Audit Quality and Audit Pricing. Auditing: A Journal of Practice \& Theory, 29(1): 73-97.

Clank, C. and Ken Levy. (2012). Improving Accountability in the Solomon Is-land: A Review of AuditorGeneral Enabling Legislation. Asia Pacific Law Re-view, 20(1): 45-62.

Creswell, J. W. (2016). Research Design-third Edition (Edisi Terjemahan). Yog-yakarta: Pustaka Belajar. DeAngelo, Linda Elizabeth. (1981). Auditor Size and Audit Quality. Journal of Accounting \& Economics, 3: 183-199.

Deli, L., Fatma, A., and Syarif, F. (2015). Faktor-Faktor Yang Mempengaruhi Kualitas Audit dengan Etika Auditor Sebagai Moderating Variabel. Jurnal Riset Akuntansi dan Bisnis, 15(1).

Deil, S. A. F. (2014). Enron, Skandal Besar Perusahaan Energi yang Cekik Investor. Retrieved from http://bisnis.liputan6.com/read/2031867/enron-skandal-besar-perusahaan-energi-yang-cekik-investor to date 31 Januari 2018.

Denzin, N., and Lincoln, Y. (1994). Handbook of Qualitative Research. London: Sage Publication. 
Fadhil, H. (2017). Disebut Dapat Rp 50 Miliar, Ini Peran Wawan di Kasus Ratu Atut. Retrieved from https://news.detik.com/berita/d-3441657/disebut-dapat-rp-50-miliar-ini-peran-wawan-di-kasus-ratu-atut to date 31 Januari 2018.

Francis, J. R., \& Yu, D.M. (2009). Big 4 Office Size and Audit Quality. The Ac-Counting Review, 84: 1521-1552.

Fauji, L., Sudarma, M., and Achsin, M. (2015). Penerapan Sistem Pengendalian Mutu (SPM) dalam Meningkatkan Kualitas Audit. Jurnal Akuntansi Multipara-digma, 6(1).

Garfinkel, H. (1967). Studies in Ethnomethodology (10th ed.). New Jersey: Pren-tice-Hall, Incl.

Goerge, J. M. \& Jones, G.R. (2005). Understanding and Managing Organizational Behavior (4th ed). New Jersey: Upper Saddle River.

Kalbers and Fogarty. (1995). "Profesionalism and Its Consequences: A Study in-Ternal Auditors", Accounting Horizon, April.

Kamayanti, A. (2016). Metodologi Penelitian Kualitatif Akuntansi (Pengantar Re-ligiositas Keilmuan). Jakarta: Yayasan Rumah Peneleh.

Lincoln, Y. S., and Guba, E. G. (1985). Naturalistic Inquiry. Retrieved from https://www .researchgate.net/publication/256294652_Naturalistic_Inquiry.

Maykut, P., and Morehouse, R. (1994). Beginning Qualitative Research. A Phisophic and Practical Guide (2nd ed.). London, UK: The Falmer Press.

Maynard, D. W., and Clayman, S. E. (1991). The Diversity of Ethnomethodology. Source: Annual Review of Sociology, 17(1991): 385-418.

Moleong, P. D. L. J. (1989). Metodologi Penelitian Kualitatif (33rd ed.). Ban-dung: PT Remaja Rosdakarya.

Moleong, L. J. (2014). Metodologi Penelitian Kualitatif. Bandung: PT. Remaja Rosdakarya.

Muawanah, Umi. (2014). Corporate Governance Dan Kepemilikan Keluarga. Jurnal Akuntansi Multiparadigma, 5(2): 287-298.

Muhajir, N. (2000). Metodologi Penelitian Kualitatif. Yogyakarta: Rake Sarasin.

Nadlir, M. (2017). Ombudsman Nilai Rektor UNJ Lakukan Maladministrasi atas Dugaan Nepotisme. Retrieved from https://nasional.kompas.com/read/2017/09/04/19560911/ombudsman-nilai-rektor-unjlakukan-maladministrasi-atas-dugaan-nepotisme to date 31 Januari 2018.

NN. (2007). Akuntan Publik Mitra Winata Dibekukan Retrieved from https://finance.detik.com/beritaekonomi-bisnis/759142/akuntan-publik-mitra-winata-dibekukan to date 31 Januari 2018.

Nindita, C., and Siregar, S. V. (2012). Analisis Pengaruh Ukuran Kantor Akuntan Publik Terhadap Kualitas Audit di Indonesia. Jurnal Akuntansi dan Keuangan, 14(2). 
Pratiwi, F and Itah, I. (2018). Price Waterhouse Dilarang Beroperasi di India Diunduh, http://www .republika.co.id/berita/ekonomi/bisnis-global/18/01/13/p2i5w4348-price-waterhouse-dilarangberoperasi-di-india to date 4 Februari 2018.

Siagian, S. P. (2014). Manajemen Sumber Daya Manusia: Bumi Aksara.

Sukoharsono, E. G. (2006). Alternatif Riset Kualitatif Sains Akuntansi: Biografi, Phenomenology, Grounded Theory, Critical Etnografi dan Case Study. Alter-natif Riset Kualitatif.

Supriadi, A. (2014). PwC: 95 Persen Perusahaan Indonesia Adalah Bisnis Keluar-ga Retrieved from https://www.cnnindonesia.com/ekonomi/20141202100356-92-15176/pwc-95-Persen-Perusahaanindon esia-adalah-bisnis-keluarga to date 12 Juli 2018.

Suraida, I. (2005). Pengaruh Etika, Kompetensi, Pengalaman Audit Terhadap Risiko Audit Terhadap Skeptisme Profesional Auditor dan Ketepatan Pemberian Opini Akuntan Publik, 7(3).

Wedemeyer, P. D. (2010). A Discussion of Auditor Judgment as the Critical Component in Audit Quality- A Practitioner's Perspective. International Journal of Disclosure and Governance, 7(4): 320333.

\section{Copyrights}

Copyright for this article is retained by the author(s), with first publication rights granted to the journal.

This is an open-access article distributed under the terms and conditions of the Creative Commons Attribution license (http://creativecommons.org/licenses/by/4.0/). 